Portland State University

PDXScholar

\title{
Hydrodynamic and Total Dissolved Solids Model of the Tigris River Using CE-QUAL-W2
}

Muhanned D. Al-Murib

Portland State University

Scott Wells

Portland State University, wellss@pdx.edu

Follow this and additional works at: https://pdxscholar.library.pdx.edu/cengin_fac

Part of the Civil and Environmental Engineering Commons

Let us know how access to this document benefits you.

\section{Citation Details}

Published as: Al-Murib, M. D., \& Wells, S. A. (2019). Hydrodynamic and Total Dissolved Solids Model of the Tigris River Using CE-QUAL-W2. Environmental Processes, 6(3) 619-641.

This Post-Print is brought to you for free and open access. It has been accepted for inclusion in Civil and Environmental Engineering Faculty Publications and Presentations by an authorized administrator of PDXScholar. Please contact us if we can make this document more accessible: pdxscholar@pdx.edu. 
Al Murib, M. D. and Wells, S. (2019) "Hydrodynamics and Total Dissolved Solids Model of the Tigris River Using CE-QUAL-W2,” Environmental Processes, DOI: 10.1007/s40710-019-00381-y

\title{
Hydrodynamic and Total Dissolved Solids Model of the Tigris River Using CE-QUAL-W2
}

\author{
Muhanned D. Al-Murib ${ }^{1}$, Scott A. Wells ${ }^{2}$ \\ ${ }^{1}$ Department of Civil and Environmental Engineering, Portland State University, United States, P.O. 751, Portland, \\ OR 97207-0751; e-mail: almuribmuhanned@gmail.com \\ ${ }^{2}$ Department of Civil and Environmental Engineering, Portland State University, United States, P.O. 751, Portland, \\ OR 97207-0751 and Collaborative Center for Geo-hazards and Eco-Environment in Three Gorges Area, Three Gorges \\ University, Yichang, China, e-mail: wellss@pdx.edu
}

Corresponding author: Muhanned Al-Murib (almuribmuhanned@gmail.com)

ORCID: 0000-0003-3950-8226

\begin{abstract}
The headwaters of the Tigris River basin in Iraq is controlled by Turkey due to a series of dams constructed overthe last few decades. Since Total Dis solved Solids (TDS) in the Tigris River within Baghdad and downstream cities can reach $1000 \mathrm{mg} / \mathrm{L}$ exceeding both drinking water and irrigation guidelines, a hydrodynamic and water quality model, CE-QUAL-W2, of the river was developed to understand how changes in flow affect TDS downstream. A model of $880 \mathrm{~km}$ of the Tigris River from MosulDam to Kut Barrage including Tharthar Lake was constructed for 2009. Model development was challenging due to a lack of in-situ measurements for calibration. Comparison of flow measurements and model predictions at downstream locations agreed well with field measurements, with model flow errors generally les s than $2 \%$. We evaluated the effect of changing upstream flow conditions on total dis solved solids concentrations in the Tigris River in order to see how headwater flow control affects TDS. A sensitivity study suggested that increasing upstream river flow by $15 \%$ results in about a $5 \%$ decrease in TDS concentration. It was recommended to maintain an average annual flow in the Tigris River within Baghdad above $420 \mathrm{~m}^{3} / \mathrm{s}$ to keep total dissolved solids concentration below $500 \mathrm{mg} / \mathrm{L}$ and to strictly control flows through Tharthar Lake and irrigation return flows into the mainstem of the Tigris River.
\end{abstract}

Keywords: The Tigris River; Hydrodynamics; Water Quality Modeling; CE-QUAL-W2. 


\section{Introduction}

The Tigris River is one of the largest rivers in the Middle East and is one of two primary rivers in Iraq (Fig. 1) that provides the primary source for drinking and irrigation water in Iraq. Fluctuation in flowrates along the Tigris River systemis the primary cause for potential flooding and drought in Iraq. Water quantity and quality of the Tigris River affects major cities along the river such as Mosul, Baeji, Tikrit, Samarra, Baghdad, Kut and Misan. Turkey contributes about 38\% of the flow of the Tigris River through the Turkey-Iraqi border and controls the headwaters of the Tigris River (FAO 2008). As a result of development of dams in the headwaters, there has been a significant reduction in the Tigris River average flow as it enters Iraq through the Turkey-Iraqi border (Al-Ansari 2013; Issa and Al-Ansari 2014; Unver 1997).

Water quality in the Tigris River has been significantly degraded and negatively impacted by major pollution sources caused by man-made activities such as discharging of untreated sewage and industrial effluents and by poor wastewater treatment infrastructure (Al-Rawi 2005). A primary indicator of water quality is total dissolved solids (TDS), since it directly limits and influences water suitability for drinking and irrigation consumption. According to WHO (2008), the optimal TDS concentration is less than $500 \mathrm{mg} / \mathrm{L}$ and becomes generally unacceptable as TDS concentration exceeds $1000 \mathrm{mg} / \mathrm{L}$. Over the length of the Tigris River, TDS concentrations have increased dramatically from MosulDam to Kut Barrage with a peak generally observed in the river section within Baghdad and downstream cities during winter seasons due to urban runoff (Rabee et al. 2011). A combination of other factors such as decreasing upstream flow at the Turkey-Iraqi border, diverting of highly saline water from Tharthar Lake, an artificial lake located $100 \mathrm{~km}$ northwest Baghdad, to the mainstem of the river through Tharthar-Tigris canal, and discharging of municipal, industrial, and agricultural return water directly into the mainstem of the Tigris River contributes to a significant increase in TDS concentration in the river (FAO 2008; Mutlak et al. 1980; Rahi and Halihan 2010). A large body of literature has provided assessments of water quality in the Tigris River and has explained potential drawbacks of degrading water quality in the river (Al-Janabi et al. 2011; Al-Jebouri and Edham 2012; AlLayla and Al-Rizzo 1989; Kadhem 2013; Khattab and Merkel 2014; Odemis et al. 2010; Varol et al. 2013).

In order to evaluate changes in TDS as a result of flow changes in the river, the two-dimensional (x-z) CE-QUALW2 model (Cole and Wells, 2017) was selected in this study primarily because of modeling stratification dynamics in Tharthar Lake and the possible extension of the study area to include the stratified Mosul Lake. Numerical modeling with CE-QUAL-W2 has been widely applied to model hydrodynamics and water quality of surface waterbodies including those with river and lake or reservoir water bodies (Kim and Kim 2006; Berger and Wells 2008; Park et al. 2014). Wells and Berger (2016) developed a hydrodynamic and water quality model of the Spokane River and Lake Spokane in eastern Washington in the United States to evaluate the assimilative capacity of the waterbody. Van Glubt, et al. (2017) evaluated the water quality of a reservoir and river system, the Chehalis River in USA, where water quality was affected by changes in hydrology and flood controloperations in upstreamheadwaters. Berger et al. (2018) evaluated the impact of an upstream lake on the water quality of the Tualatin River using CE-QUAL-W2. Emphasizing the importance of stratification impacts on water quality, Ma et al. (2015) modeled density currents in a typical tributary (Xiangxi Bay XXB) of the Three Gorges Reservoirs in China using the numerical model CE-QUAL-W2 to study the relationship between phytoplankton and density currents.

The model of the Tigris River was developed and calibrated based on limited field data. In this paper, we investigate the feasibility and utility of using CE-QUAL-W2 to study the impacts on TDS concentrations as a result of altering the upstream hydrological conditions in the Tigris River. 


\section{Material and Methods}

\subsection{The Tigris River Study Area}

Along with the Euphrates River, the $1850 \mathrm{~km}$ long Tigris River forms the primary freshwater system in Iraq. About $58 \%$ of the Tigris basin lies within Iraq with a catchment area of $253,000 \mathrm{~km}^{2}$. The average annual flow of the Tigris River is $672 \mathrm{~m} / \mathrm{s}$ as it enters Iraq, with a mean average of $701 \mathrm{~m}^{3} / \mathrm{s}$ during 1960-1984 dropping to $596 \mathrm{~m}^{3} / \mathrm{s}$ during 1985-2008 (Al-Ansari and Knutsson 2011). Generally, peak flows in the Tigris River occur between April and May. Our study area extends from Mosul Dam (River kilometer, Rkm, 0 at the most upstream model segment) to Kut Barrage (Rkm 880), as shown in Fig. 1. Four tributaries join the Tigris River study area: The Upper Zab (Rkm 120), the Lower Zab (Rkm 240), Audaim River (Rkm 458), and Diyala River (Rkm 605), as shown in Fig. 1. Excess fresh water from the Tigris River at Samarra Barrage, located $125 \mathrm{~km}$ upstream of Baghdad, is diverted to Tharthar Lake, an artificial lake located $100 \mathrm{~km}$ northwest of Baghdad, through the Tigris-Tharthar canal, $75 \mathrm{~km}$ long, to prevent potential flooding in Baghdad. High saline water is diverted from the lake to the Tigris River through the $65 \mathrm{~km}$ long Tharthar-Tigris canal, which is located $25 \mathrm{~km}$ upstream of Baghdad, during dry seasons. Tharthar Lake and its canals are also included in the Tigris River model.

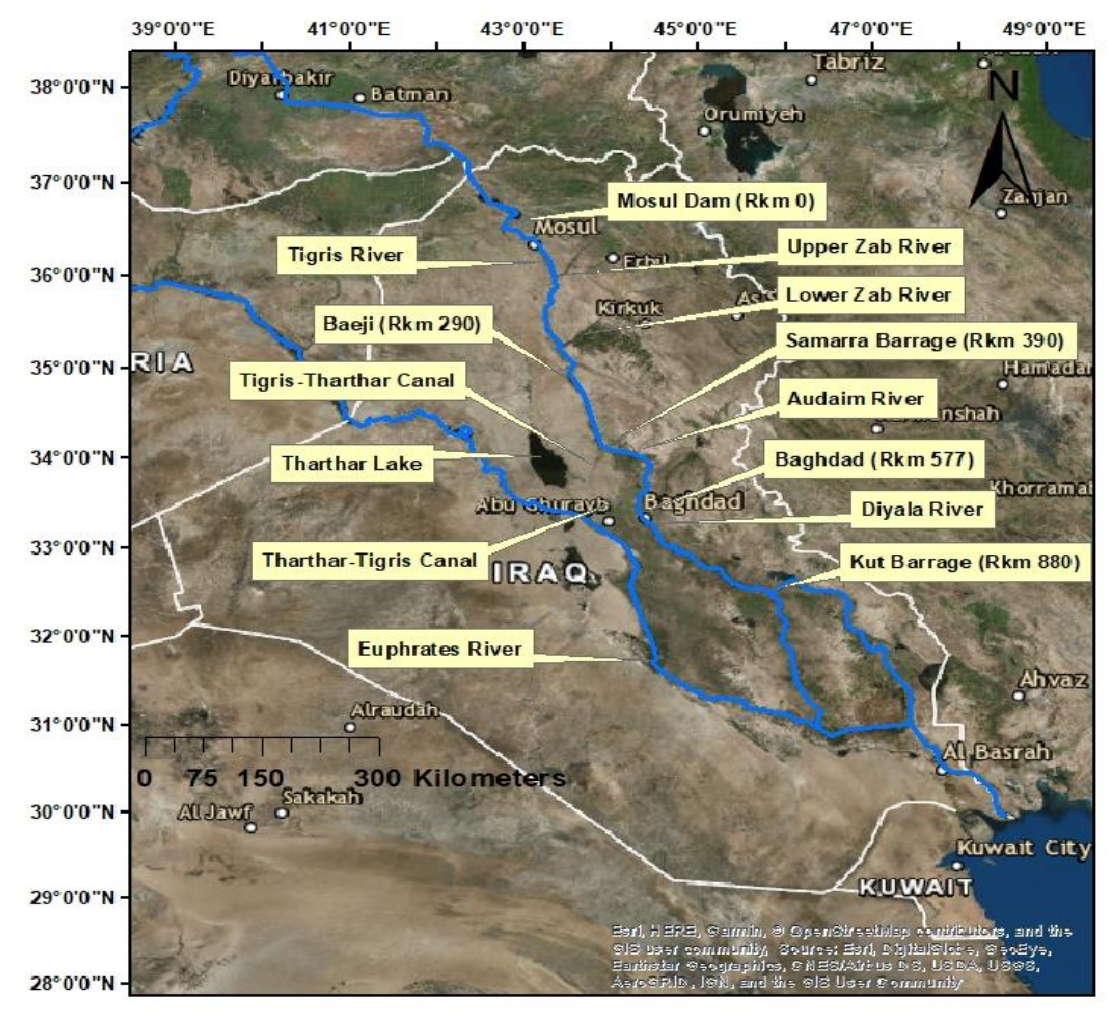

Fig. 1 The Tigris River study area from Mosul Dam (River km 0) to Kut Barrage (River Km 880) (ArcMap).

\subsection{Model Description and Performance Assessment}

We use the 2-D numerical model CE-QUAL-W2 (W2) to model flow, stage, water temperature and total dissolve solids (TDS) in the Tigris River systemincluding Tharthar Lake. W2 is a two-dimensional (longitudinal and vertical) water quality model developed by the U.S. Army Corps of Engineers and Portland State University (Cole and Wells 2017). W2 describes river/reservoir water levels, vertical and horizontal velocities, water temperature, and a userdefined number of water quality constituents including TDS, nutrients, algae, dissolved oxygen, and suspended 
sediment. W2 has been applied to over a thousand reservoirs, lakes and river systems all over the world (Cole and Wells 2017). The governing equations of CE-QUAL-W2 are shown in the Appendix.

To evaluate the model performance, we use the mean error (ME) that shows model bias, the absolute mean error (AME) that provides an indication of model performance and is a measure of the average error, and the root mean square error (RMSE) that shows the average difference between observations and predictions. The goodn ess of fit statistics of the model to the observed data were calculated as follows:

$\mathrm{ME}=\frac{\sum_{\mathrm{i}=1}^{\mathrm{n}}\left(\mathrm{X}_{\mathrm{obs}, \mathrm{i}}-\mathrm{X}_{\text {model }, \mathrm{i}}\right)}{\mathrm{n}}$

$\mathrm{AME}=\frac{\sum_{\mathrm{i}=1}^{\mathrm{n}}\left|\mathrm{X}_{\mathrm{obs}, \mathrm{i}}-\mathrm{X}_{\text {model }, \mathrm{i}}\right|}{\mathrm{n}}$

$\operatorname{RMSE}=\sqrt{\frac{\sum_{i=1}^{n}\left(X_{o b s, i}-X_{\text {model }, i}\right)^{2}}{n}}$

Where: $n$ : number of observations; $X_{o b s, i}:$ the value of the ith observation of parameter $X ; X_{\text {model, }, i}$ the predicted value of the ith observation of parameter $\mathrm{X}$.

\subsection{The Tigris River Model Setup and Development}

The Tigris River mainstem, Tharthar Lake and its canals, were divided into waterbodies (i.e., a collection of model branches that have similar turbulence closure and water quality parameter values and meteorological forcing), branches (i.e., a collection of model segments with variable model slope or a reservoir with multiple side arms), segments (i.e., a longitudinal segment of length $\Delta \mathrm{x}$ ), and layers (i.e., a vertical layer of height $\Delta \mathrm{z}$ ). The Tigris River systemmodel setup and input data required to run the model are described in the following section.

\subsubsection{The Tigris River Model Setup}

The mainstem of the Tigris River was discretized into four waterbodies (Wb1, Wb2, Wb3, and Wb4) as listed in Table 1. Latitude and longitude, bottom elevation of the grid, starting and ending branches of the waterbody were defined for each waterbody. Since the channel slope varies, the mainstem of the river was divided into four branches $(\mathrm{Br} 1$, $\mathrm{Br} 2, \mathrm{Br} 3$, and Br4). Tigris-Tharthar Canal, Tharthar Arm, Tharthar-Tigris Canal, Tharthar Lake, and Erwaeiya canal were also included in the model and were discretized into five separate waterbodies (Wb5, Wb6, Wb7, Wb 8, and Wb9) with five separate branches (Br5, Br6, Br7, Br8, and $\mathrm{Br} 9)$, respectively. By defining upstream and downstream external/internal flow, internal head, or dam flow boundary condition, all model branches were connected. Gates, spillways, and hydraulic structures were defined to convey water through the system (Fig. 2).

Table 1 Dimensions of all waterbodies and branches of the Tigris River System (DS: Downstream, B: Barrage)

\begin{tabular}{cccccccc}
\hline $\begin{array}{l}\text { Water } \\
\text { Body } \\
(\mathrm{Wb})\end{array}$ & $\begin{array}{c}\text { Branch } \\
(\mathrm{Br})\end{array}$ & $\begin{array}{c}\text { Starting } \\
\text { Active } \\
\text { Segment }\end{array}$ & $\begin{array}{c}\text { Ending } \\
\text { Active } \\
\text { Segment }\end{array}$ & $\begin{array}{c}\text { Branch } \\
\text { Length } \\
(\mathrm{km})\end{array}$ & $\begin{array}{c}\text { Number } \\
\text { of } \\
\text { Segments }\end{array}$ & $\begin{array}{c}\text { Number } \\
\text { of } \\
\text { Vertical } \\
\text { layers }\end{array}$ & Details \\
\hline Wb1 & Br1 & 2 & 70 & 350 & 69 & 82 & $\begin{array}{c}\text { From Mosul Dam to 15 km } \\
\text { DS of Tikrit }\end{array}$ \\
Wb2 & $\mathrm{Br} 2$ & 73 & 80 & 40 & 8 & 82 & $\begin{array}{c}\text { From 15 km DS of Tikrit to } \\
\text { Samarra Barrage. }\end{array}$
\end{tabular}




\begin{tabular}{|c|c|c|c|c|c|c|c|}
\hline $\mathrm{Wb} 3$ & $\mathrm{Br} 3$ & 83 & 137 & 256.5 & 55 & 82 & $\begin{array}{c}\text { From Samarra Barrage to } 70 \\
\text { km DS of Baghdad }\end{array}$ \\
\hline Wb4 & $\mathrm{Br} 4$ & 140 & 189 & 233.5 & 50 & 82 & $\begin{array}{c}\text { From } 70 \mathrm{~km} \text { DS of Baghdad } \\
\text { to Kut Barrage }\end{array}$ \\
\hline Wb5 & $\mathrm{Br} 5$ & 192 & 206 & 75 & 15 & 82 & Tigris-Tharthar Canal \\
\hline Wb6 & $\mathrm{Br} 6$ & 209 & 297 & 90 & 89 & 82 & Tharthar Lake \\
\hline Wb7 & $\mathrm{Br} 7$ & 300 & 305 & 27 & 6 & 82 & Tharthar Arm \\
\hline Wb8 & $\mathrm{Br} 8$ & 308 & 320 & 65 & 13 & 82 & Tharthar-Tigris Canal \\
\hline Wb9 & $\operatorname{Br} 9$ & 323 & 342 & 97 & 20 & 82 & $\begin{array}{l}\text { From Samarra Barrage to } \\
\text { Tharthar Regulator }\end{array}$ \\
\hline
\end{tabular}

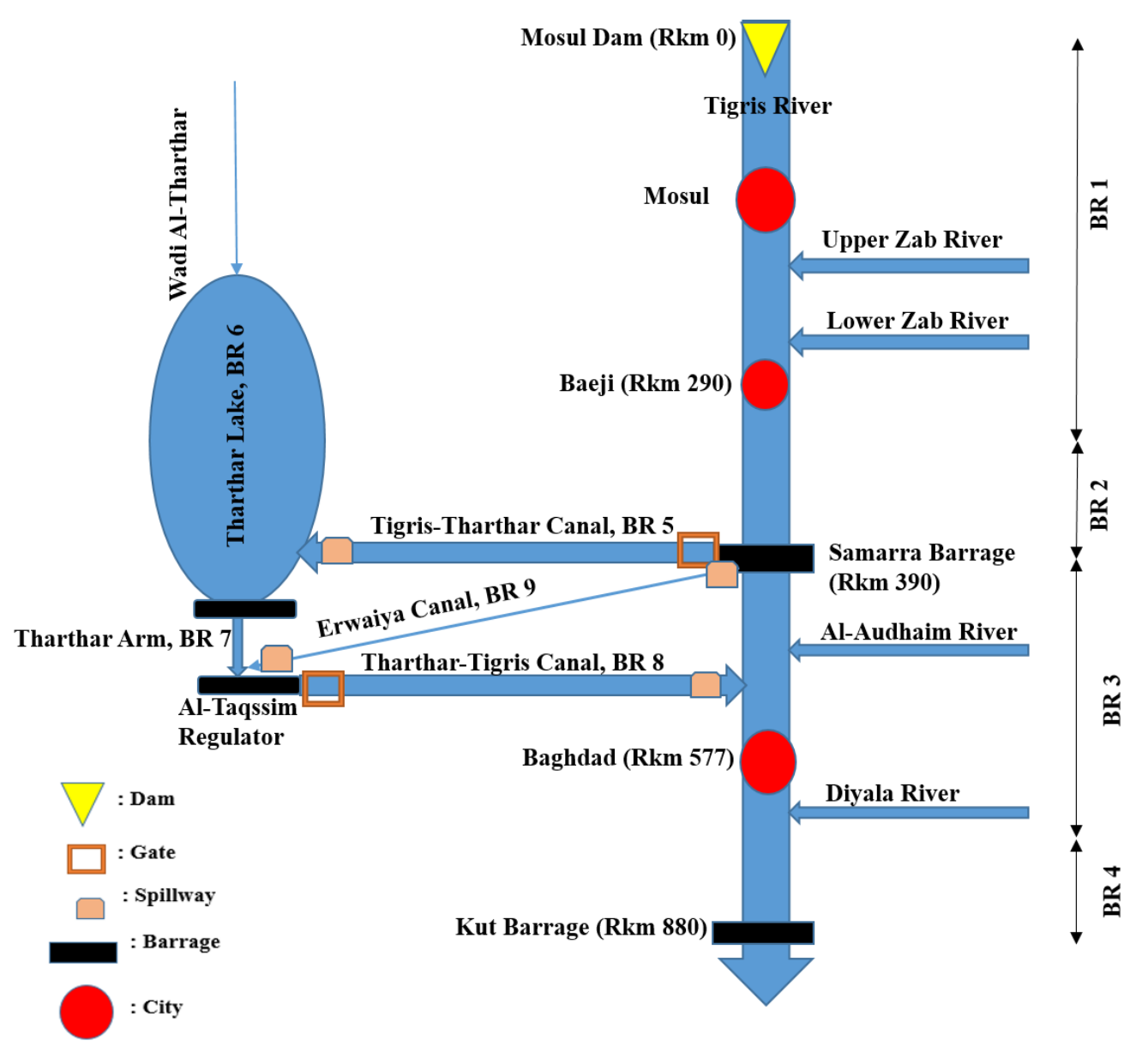

Fig. 2 Schematic diagram of the Tigris River system. BR represents model branch. 


\subsubsection{Bathymetry and Grid Development}

The Tigris River cross sections at $5 \mathrm{~km}$ increments from MosulDam (Rkm 0) to Kut Barrage (Rkm 880) were provided from the Iraqi Water Resources Ministry (Fig. 1) and were used to develop the river grid for the CE-QUAL-W2 model (Al-Murib 2014). Some missing cross sections were filled using linear interpolation. The bottom elevation of the river (Fig. 3) was estimated using bathymetric data. The model grid of the Tigris River systemconsisted of 343 longitudinal segments. Each model segment had $1 \mathrm{~m}$ vertical layer thickness. In addition, the topographic and the morphology of Tharthar Lake from Sissakian (2011) was used to construct the grid for Tharthar Lake (Fig. 4). A set of polygons along the North/South axis of the lake was created and subsequently the volume/area elevation curves of Tharthar Lake were produced and were used to determine the cross-sections of each model segment.

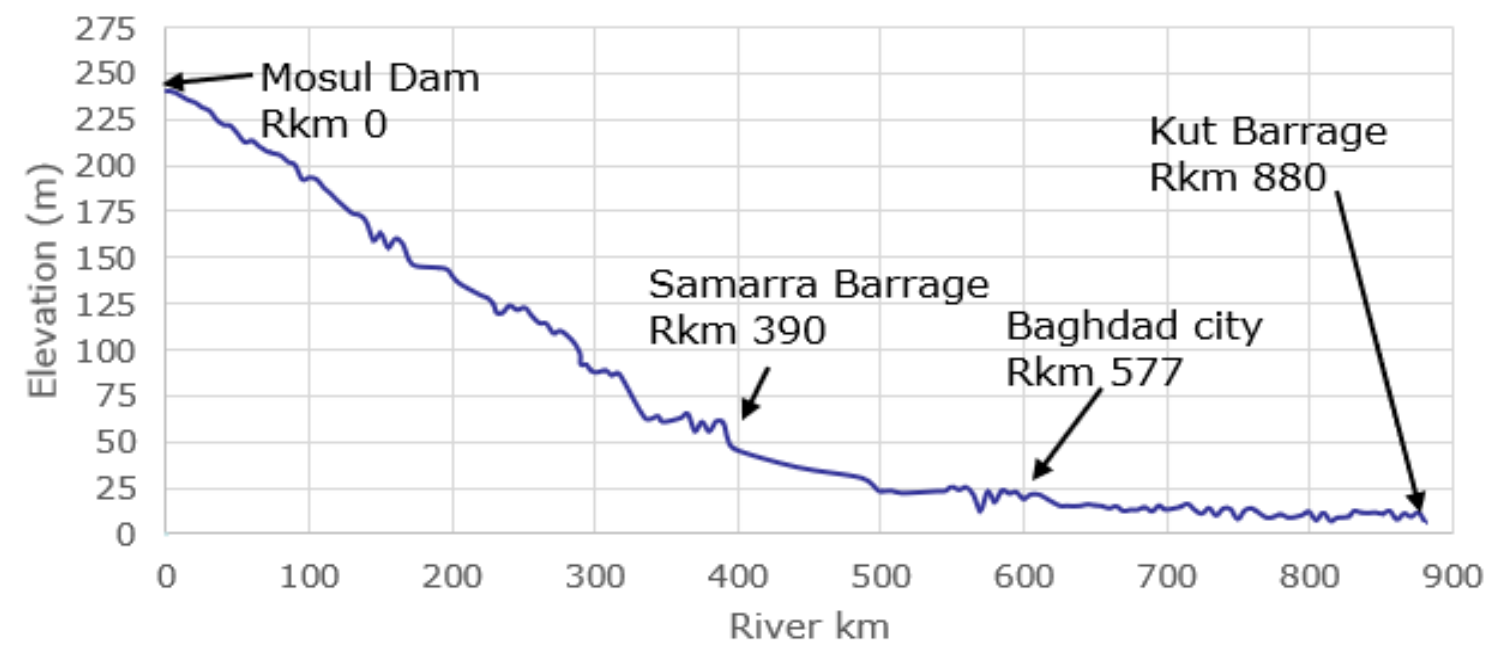

Fig. 3 Bottom elevation of the mainstem of the Tigris River study area from Mosul Dam to Kut Barrage.
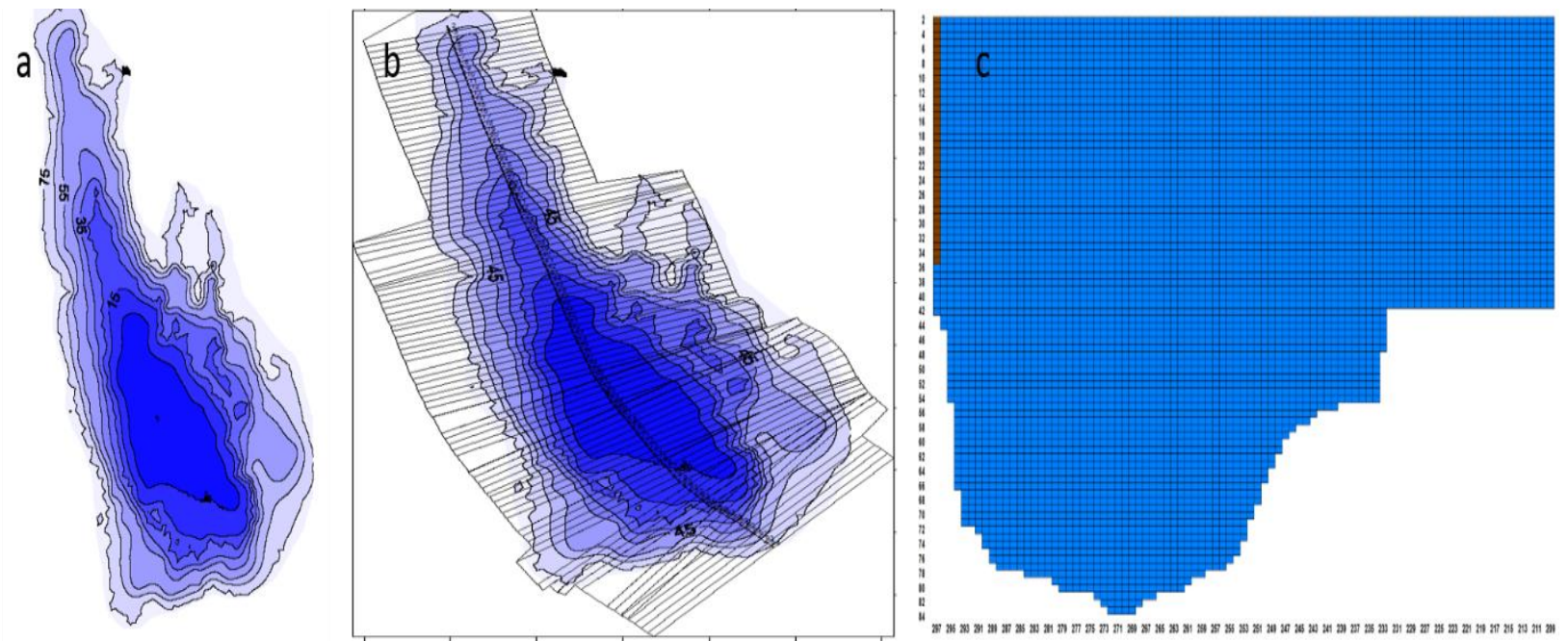

Fig. 4 Tharthar Lake grid: (a) contour lines in meters based on Sissakian (2011); (b) model segments of Tharthar Lake; and (c) model side view of longitudinal profile of Tharthar Lake (on the left is the outlet of the lake at segment 297 with a brown color). 


\subsection{Model Input Data}

\subsubsection{Flow and Water Level}

Field data of flowrates (Fig. 5) and water level in the mainstem of the Tigris River (Table 2) were provided from the Iraqi Ministry of Water Resources (IMWR) for the simulation period from January 1, 2009 to December 31, 2009. In 2009, the Tigris River within Iraq received waters from the upper Tigris Basin, the Upper Zab River, the Lower Zab River, the Diyala River and the Audaim River, with contributions of approximately 52\%, 33\%, 8\%, 6.2\% and 0.78\%, respectively, of the total flow in the river (CSO 2010). The Upper Zab River is the largest contributor compared with all tributaries inside Iraq, while the Audaim River had little impact on the Tigris River flow. With no dams, the Upper Zab River is an uncontrolled tributary. Although flowrate data were unavailable for both the Upper Zab River and the Lower Zab River, daily flowrates at theses tributaries were estimated by computing a daily flow difference between Mosul Dam and Baeji. The difference in flow was allocated at $80 \%$ for the Upper Zab River and 20\% for the Lower Zab River according to CSO (2010). Daily average flowrates of the Audaim River were provided from the IMWR, while monthly average flowrates in the Diyala River were estimated from CSO (2010). About $6 \%$ of the average water in the Tigris River was withdrawn from the main stream of the river within Baghdad in 2009 to supply eight water treatment plants located on both river banks. These withdrawals were specified in the model according to the produced capacity of each treatment plant. Other inflows, such as precipitation, flowrate from wastewater treatment plants (WWTPs), agricultural return flows, and flowrate of groundwater, were unavailable but were accounted for within the model by using a distributed tributary where flow is added to every segment in a branch rather than at one segment. Distributed tributary flowrates were estimated by performing a water balance during flow calibration.

Table 2: Field data of the Tigris River model.

\begin{tabular}{cccc}
\hline Station & River km & Field Data & Frequency \\
\hline MosulDam & 0 & Flow & Daily \\
Baeji & 290 & Flow, Stage & Daily \\
Discharge from & 390 & Flow & Daily \\
Samarra Barrage & & & \\
Baghdad & 577 & Flow, Stage & Daily \\
Kut Barrage & 880 & Flow & Daily \\
\hline
\end{tabular}



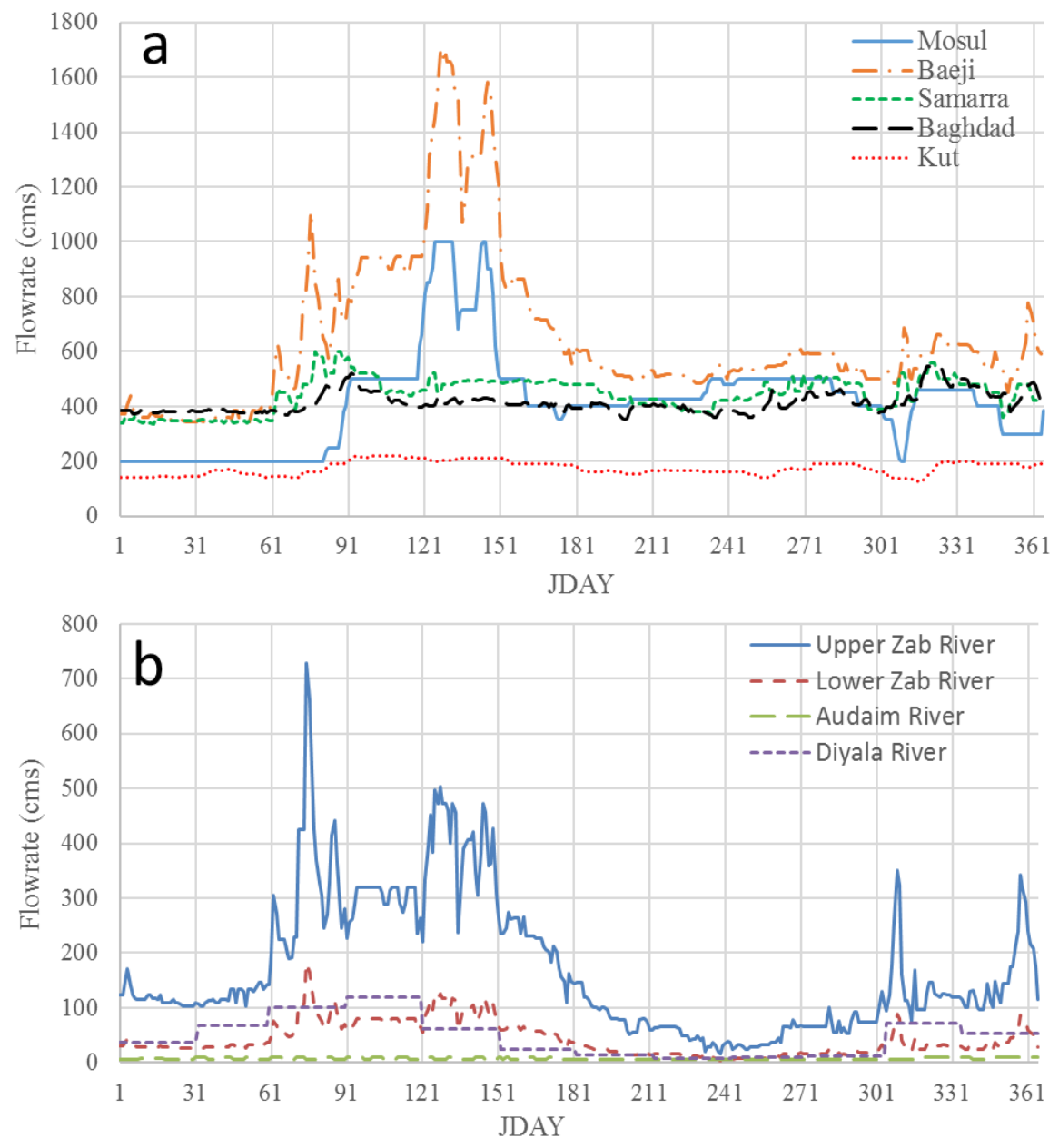

Fig. 5 Daily flowrates of the Tigris River in 2009 at: (a) mainstem; and (b) tributaries.

\subsubsection{Total Dissolved Solids}

Input concentrations of total dissolved solids (TDS) were required for the entire simulation time for all inflows. Monthly averaged field data of TDS (Fig. 6) were provided from the IMWR for the mainstem of the Tigris River at Mosul Dam, Samarra Barrage, Baghdad, and Kut Barrage. The IWRM also provided TDS concentrations for both Audaim and Diyala tributaries, while TDS concentrations in the Upper Zab and the Lower Zab tributaries were unavailable and were assumed to be the same as in Mosul and Samarra, respectively. Hence, the model linearly interpolated between monthly averaged TDS concentrations for all model inflows. TDS concentrations in the Tigris River started to significantly increase downstream of Samarra Barrage at Baghdad and Kut where water exceeds the optimum TDS concentration of less than $500 \mathrm{mg} / \mathrm{L}$. Generally, the water in the Tigris River at Kut is unacceptable for most uses as TDS concentration is above $1000 \mathrm{mg} / \mathrm{L}$. According to Aziz and Aws (2012), the average TDS concentrations at the main three sewage treatment plants in Baghdad discharged into the Tigris river system are 2644 $\mathrm{mg} / \mathrm{L}, 1766 \mathrm{mg} / \mathrm{L}$, and $2507 \mathrm{mg} / \mathrm{L}$ at Karkh, Old Rustumiyah, and New Rustumiyah, respectively. 


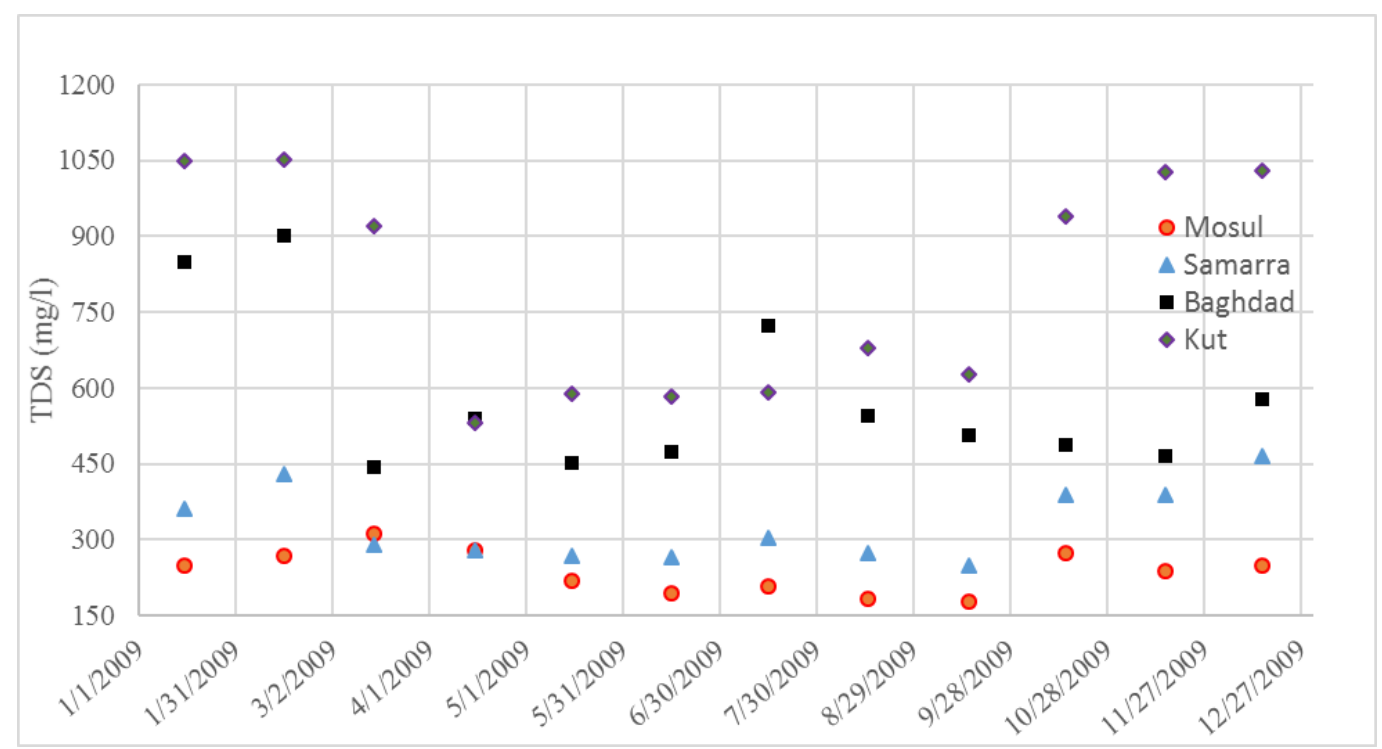

Fig. 6 Field data of total dissolved solids in the Tigris River in 2009.

\subsubsection{Meteorological Data of the Tigris River Model}

W2 utilizes air and dew point temperature, wind speed and direction, and cloud cover and solar radiation. Meteorological data for the year 2009 were provided for three cities from the Iraqi Meteorological Organization and Seismology. Available meteorological data include air temperature, dew point temperature, wind speed and direction, and cloud cover every 4 hours at Mosul, Baeji, and Baghdad. Spatially, meteorological data at Mosul covered the study area from Mosul Dam (Rkm 0) to Baeji (Rkm 290), meteorological data at Baeji covered the study area from Baeji (Rkm 290) to Samarra Barrage (Rkm 390), and data at Baghdad covered the region from Samarra Barrage to Kut Barrage (Rkm 880).

\section{Model Calibration}

The mainstream of the river from Mosul Dam (River km 0) to Kut Barrage (River km 880), in addition to Tharthar Lake and its canals, were simulated and calibrated for the year 2009. Model predictions compared to field data included flow and stage, water temperature, and TDS.

\subsection{Flow Calibration}

\subsubsection{Tharthar Lake}

According to CSO (2010), the water level in Tharthar Lake dropped from $45.75 \mathrm{~m}$ in October 2008 to $44 \mathrm{~m}$ in October 2009. The initial condition of water level in the lake was assumed at $45.5 \mathrm{~m}$ in January 1st, 2009. The water level in the lake was controlled by the amount of flow input through the Tigris-Tharthar canal and was calibrated to only one data point in October 2009 (Fig. 7). Model calibration of the water level in the lake was carried out through multiple iterations by adjusting the outflow from Tharthar Lake which was diverted to both the Euphrates River through Tharthar-Euphrates canal and to the Tigris River through Tharthar-Tigris canal. Flowrates through the Tharthar-Tigris canal were assumed, while the excess lake's water was diverted to the Euphrates River. During Spring freshet in May 2009, a large volume of fresh water was diverted to Tharthar Lake through Tigris -Tharthar canal causing a significant 
increase in the lake's stage. Evaporation in Tharthar Lake was a significant factor that affected the water level, temperature, and TDS in the lake. Model predictions of evaporation in Tharthar Lake was $2.2 \mathrm{~m}$ for the simulated year 2009 and agreed with the annual evaporation of $2.27 \mathrm{~m}$ measured in Haditha Lake, $60 \mathrm{~km}$ northwest Tharthar Lake, during the water year 2008-2009 (CSO 2010). The W2 evaporation model (Cole and Wells 2017) was based on the W2 model default evaporation wind speed function, $f(W)=9.2+0.46 W^{2}$, where $\mathrm{f}(\mathrm{W})$ is in units of $\mathrm{W} \mathrm{m}^{-2}(\mathrm{~mm}$ $\mathrm{Hg})^{-1}, \mathrm{~W}$ is the wind speed at $2 \mathrm{~m}$ height in $\mathrm{m} / \mathrm{s}$. This was used in conjunction with the model prediction of temperature and available meteorological data computing evaporative mass loss, $\mathrm{E}$ in $\mathrm{kg} / \mathrm{m}^{2} / \mathrm{s}$, from $E=L_{v}^{-1} f(W)\left(e_{s}-e_{a}\right)$ where $\mathrm{L}_{\mathrm{v}}$ is the latent heat of vaporization in $\mathrm{J} \mathrm{kg}^{-1}$, $e_{\mathrm{s}}$ is the saturated vapor pressure at the surface temperature and $\mathrm{e}_{\mathrm{a}}$ is the vapor pressure of the air in $\mathrm{mm} \mathrm{Hg}$.
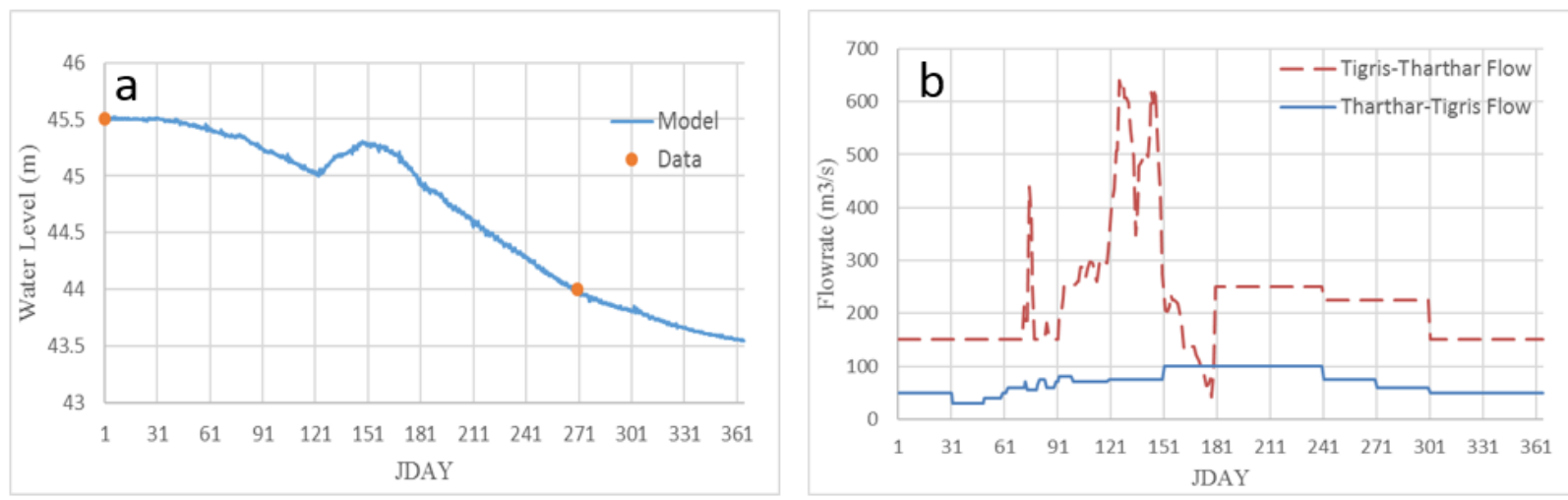

Fig. 7 Model predictions for: (a) water level in Tharthar Lake in 2009; and (b) flowrates in the Tigris-Tharthar canal and Tharthar-Tigris canal.

\subsubsection{The Tigris River}

The model calibration of flowrate and water level along the mainstem of the Tigris River started at the upstream portions of the model and moved downstream comparing model predictions of flow and water level to field data of flow and water level provided by the IMWR at Baeji, Samarra Barrage, and Baghdad for the model simulation year 2009. However, flow data were likely to contain uncertainty due to random and systematic errors in measuring gaged stream flow (Baldassarre and Montanari 2009; Cohn et al. 2013). Flow and water level at Baeji, Samarra Barrage, and Baghdad were compared in Fig. 8. The flow calibration process was based on adding or subtracting flow through a distributed tributary that accounted for ungaged inflows during storm events or outflow from the systemsuch as from numerous ungaged irrigation withdrawals along the river banks. Flow calibration by adding a distributed tributary was done through multiple iterations until model predicted flows agreed with field data. The percentage error of flowrate at Baeji, Samarra Barrage, and Baghdad were 1.93\%, 0.83\%, and 0.81\%, respectively. Calibration of the water level was carried out by adjusting Manning's coefficients, branch slope and bottom elevation. The absolute mean errors for water level and flowrate were $0.04 \mathrm{~m}$ and $12.57 \mathrm{~m}^{3} / \mathrm{s}$ at Baeji, $0.02 \mathrm{~m}$ and $3.67 \mathrm{~m}^{3} / \mathrm{s}$ at Samarra Barrage, and $0.02 \mathrm{~m}$ and $3.39 \mathrm{~m}^{3} / \mathrm{s}$ at Baghdad. Error statistics for model comparisons with the field data are listed in Table 3. This compares to similar studies using CE-QUAL-W2 modeling and calibrating the Chehalis River, about $200 \mathrm{~km}$, located in the southwest region of Washington State in the United States (Van Glubt et al. 2017). Distributed tributaries were also used in this study to calibrate for ungaged inflows and outflows in the river; model results showed an average absolute mean error of $5 \mathrm{~m}^{3} / \mathrm{s}$ overall in the study area where in-stream flows varied to a peak of $750 \mathrm{~m}^{3} / \mathrm{s}$. 

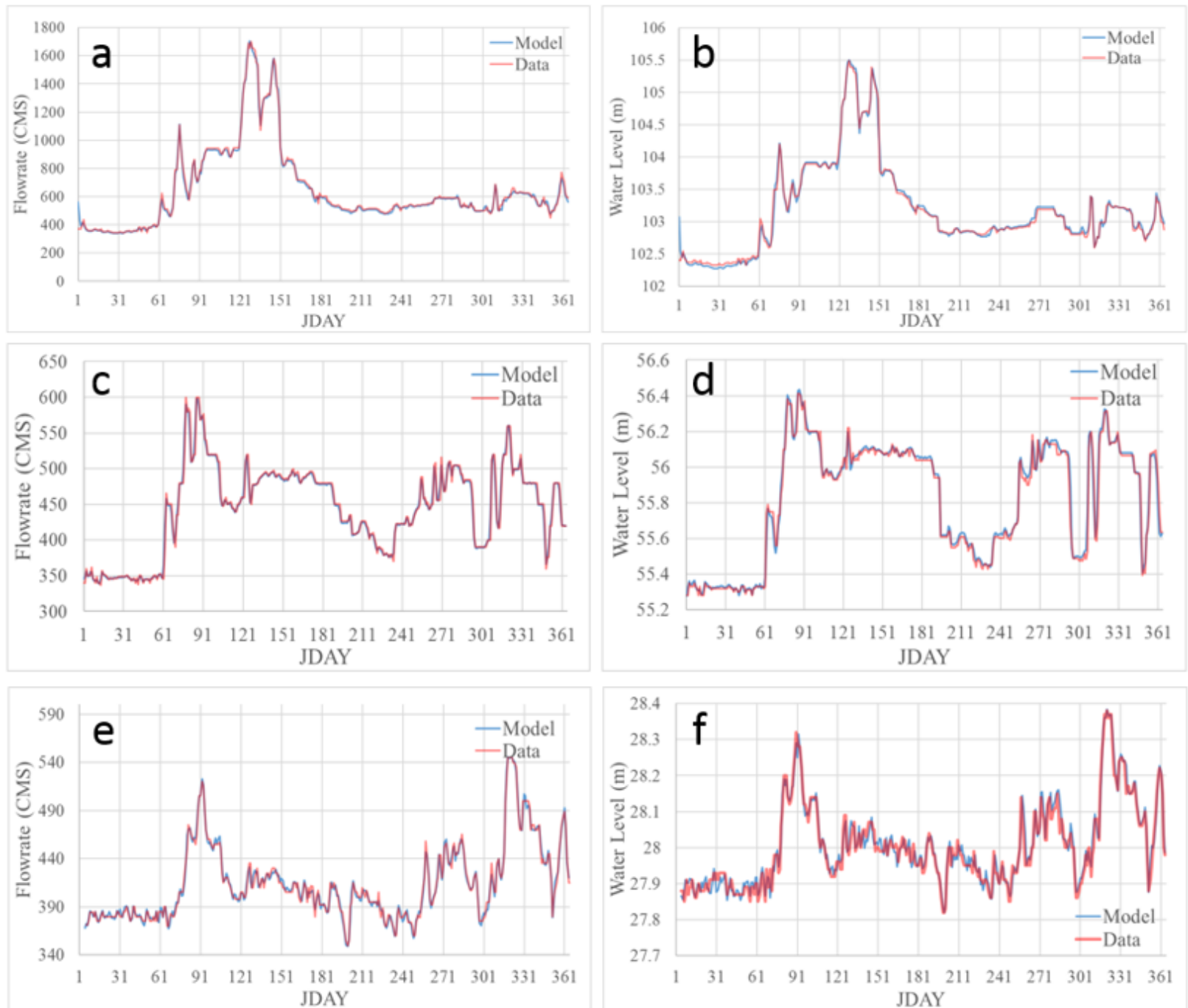

Fig. 8 Model predictions of flowrate and water level at: (a, b): Baeji; (c, d) Samarra Barrage; and (e, f) Baghdad.

Table 3: Error statistics for model comparisons to field data for flow and water level (W.L.)

\begin{tabular}{ccccccc}
\hline \multirow{2}{*}{ Error } & \multicolumn{2}{c}{ Baeji } & \multicolumn{2}{c}{ Samarra Barrage } & \multicolumn{2}{c}{ Baghdad } \\
& W.L. & Flow $\left(\mathrm{m}^{3} / \mathrm{s}\right)$ & $\begin{array}{c}\text { W.L. } \\
(\mathrm{m})\end{array}$ & Flow $\left(\mathrm{m}^{3} / \mathrm{s}\right)$ & $\begin{array}{c}\text { W.L. } \\
(\mathrm{m})\end{array}$ & Flow $\left(\mathrm{m}^{3} / \mathrm{s}\right)$ \\
\hline ME & 0.001 & -5.989 & 0.008 & -0.731 & 0.003 & 0.031 \\
AME & 0.037 & 12.574 & 0.023 & 3.673 & 0.019 & 3.388 \\
RMSE & 0.057 & 17.036 & 0.038 & 6.921 & 0.025 & 4.475 \\
\# of & 360 & 360 & 360 & 360 & 360 & 360 \\
comparisons, $n$ & & & & & & \\
\hline
\end{tabular}


Model distributed tributaries and inflows are shown in Fig. 9. Distributed tributaries at Baghdad (Fig. 9b) and Kut (Fig. 9c) mostly had negative flows, indicating water being withdrawn from the system because of irrigation. Crops are mainly produced in the irrigated areas in central and southern Iraq using irrigation water from the Tigris River (FAO 2012). Moreover, crops in the Mesopotamian Plain require intensive irrigation due to low annual rainfall, hot summers, and very high evaporation rates (FAO 2008). Generally, winter crops are produced during the period from October to May, and summer season crops are produced from March to September. We compared model distributed tributaries with estimated irrigation demand along the Tigris River at Baghdad, Diyala and Kut. The irrigation land in each area was provided from CSO (2010). Assuming $12.7 \mathrm{~cm}$ depth of water required for irrigated crops over a year, the estimated amounts of irrigation demand in Baghdad, Diyala and Kut are listed in Table 4. It was found that average model estimation of irrigation flows as distributed tributaries at Baghdad and Kut was about $95 \mathrm{~m}^{3} / \mathrm{s}$ and $200 \mathrm{~m}^{3} / \mathrm{s}$ compared with the estimate of irrigation demand of $76 \mathrm{~m}^{3} / \mathrm{s}$ and $250 \mathrm{~m}^{3} / \mathrm{s}$, respectively. 

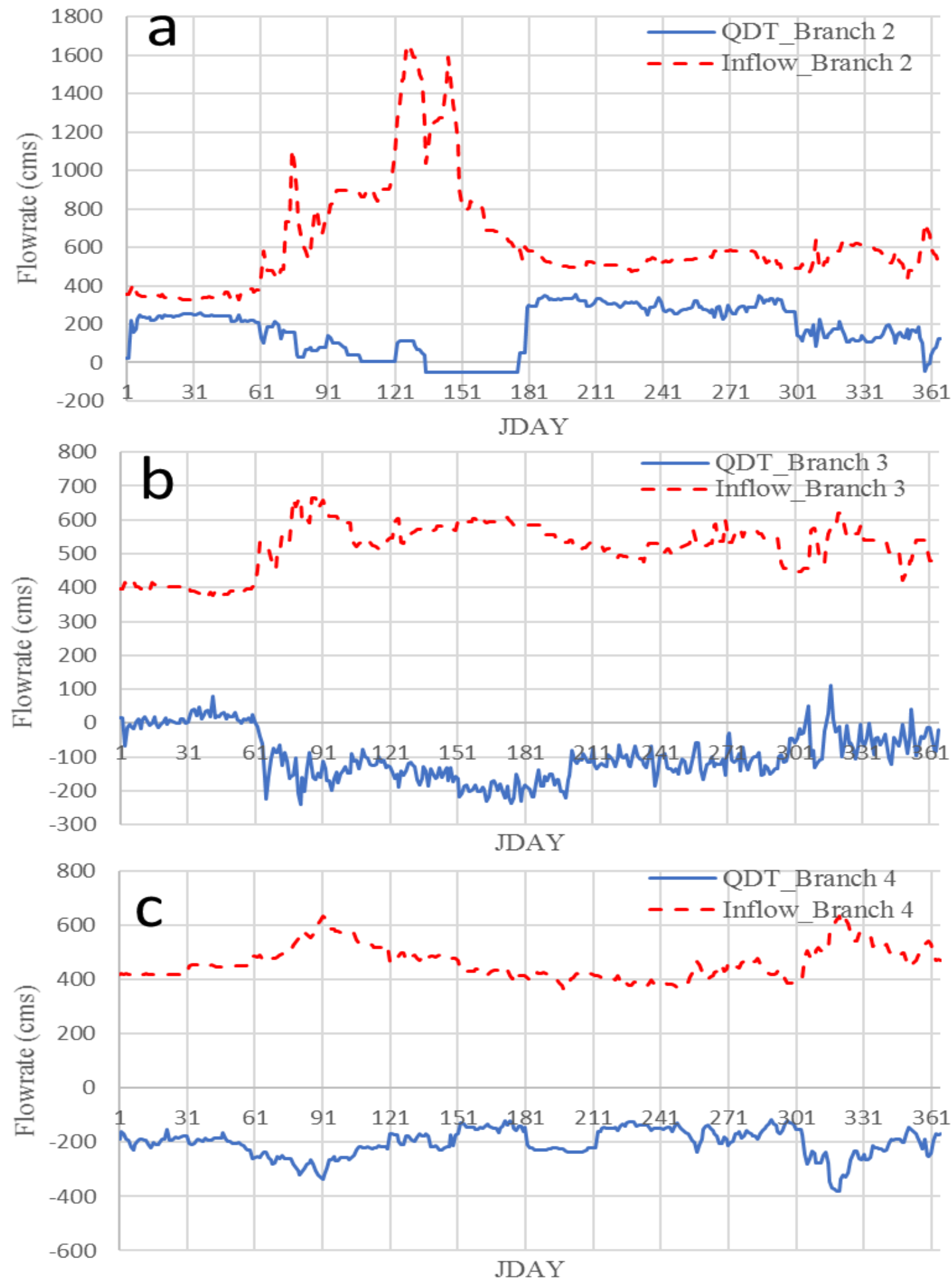

Fig. 9 Inflow and distributed flow (QDT) of the Tigris River model in: (a) model branch 2; (b) model branch 3; and (c) model branch 4. 
Table 4 Model and theoretical estimation of irrigation water in Baghdad, Diyala and Kut

$\begin{array}{ccc}\text { Tity } & \begin{array}{c}\text { Total Irrigated } \\ \text { Area (Dunam) } \\ \text { CSO (2010) }\end{array} & \text { Total Irrigated } \\ \text { Area }\left(\mathrm{m}^{2}\right)\end{array}$
Model Estimation of Irrigation as Distributed Tributary $\left(\mathrm{m}^{3}\right)$
Theoretical Estimation of Irrigation $\left(\mathrm{m}^{3}\right)$

\begin{tabular}{ccccc}
\hline $\begin{array}{c}\text { Baghdad } \\
\text { and Diyala }\end{array}$ & $18,940,000$ & $18.94 \mathrm{E}+09$ & $3.00 \mathrm{E}+09$ & $2.40 \mathrm{E}+09$ \\
Kut & $62,210,000$ & $62.21 \mathrm{E}+09$ & $6.35 \mathrm{E}+09$ & $8.00 \mathrm{E}+09$ \\
\hline
\end{tabular}

Water depths along the Tigris River were sensitive to the channel friction as represented by the Manning coefficient. The adjustment of the Manning friction coefficient was used to match water level to field data. About 74\% of the Tigris River bed within Mosulcity is very coarse gravel (Othman and Deguan 2004), while the bed of the Tigris River within Baghdad city is mainly covered by sand (Ali et al. 2012; Al-Ansari et al. 2015). Manning coefficients in the Tigris River (Table 5) were selected based on values reported by Chow (1959). In Baghdad, 13 bridges were constructed on the Tigris River, while only five bridges were constructed on the Tigris River within Mosul (Fig. 10). Bridge piers are obstacles to stream flows and cause backwater and consequently cause an effective increase in Manning coefficient (Charbeneau and Holley 2001). High Manning friction in the Tigris River within Baghdad is due to the effect of channel irregularity (scoured banks), channelobstruction (debris deposits and bridge piers), the degree of meandering, and imperfections in the cross-sectional geometry.
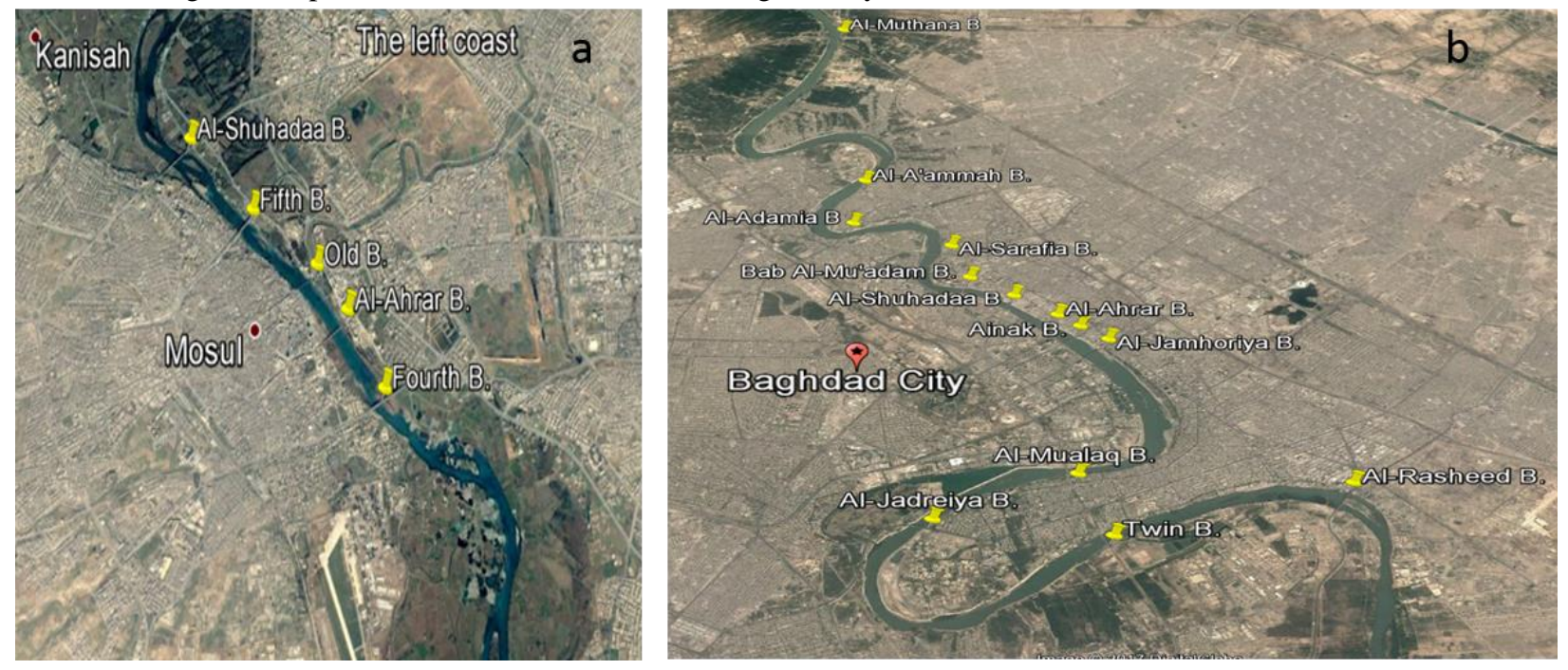

Fig. 10 Bridges and meandering on the Tigris River at: (a) Mosul; and (b) Baghdad (Google Earth).

Table 5: Manning coefficients and slopes used in the Tigris River model

\begin{tabular}{cccc}
\hline $\begin{array}{c}\text { Model } \\
\text { Branch }\end{array}$ & $\begin{array}{c}\text { Manning's } \\
\text { Coefficients }\end{array}$ & Slope & Details \\
\hline 1 & 0.025 & 0.00054 & From Mosul Dam to 15 km Downstream \\
of Tikrit
\end{tabular}




\begin{tabular}{cccc}
2 & 0.025 & 0 & $\begin{array}{c}\text { Samarra Barrage } \\
3\end{array}$ \\
0.050 & 0.000154 & $\begin{array}{c}\text { From Samarra Barrage to 70 km } \\
\text { Downstream of Baghdad }\end{array}$ \\
4 & 0.050 & 0 & Kut Barrage \\
5 & 0.011 & 0.00012 & Tigris-Tharthar Canal \\
6 & 0.011 & 0 & Tharthar Lake \\
7 & 0.011 & 0.00011 & Tharthar Arm \\
8 & 0.011 & 0.0002 & Tharthar-Tigris Canal \\
9 & 0.011 & 0.0001 & Erwaeiya Canal \\
\hline
\end{tabular}

\subsection{Temperature Calibration}

Water temperature in the Tigris River was calibrated after the flowrate calibration was finalized since water temperature was dependent on water depth. Water temperatures in the Tigris River were also affected by hydrologic and climate conditions. Due to a lack of the in situ measurements for calibration, we used remote sensing technique to estimate water temperature in the Tigris River. Statistical models based on satellite imagery at Mosul Dam, Baeji and Baghdad were developed to estimate daily water temperature for upstream boundary conditions and downstream model calibration. Modeled temperatures had an AME at several locations including Tharthar Lake of about $1{ }^{\circ} \mathrm{C}$ using satellite estimates of inflow and in situ temperatures. A full description of the temperature modeling in the Tigris River is shown in Al Murib (2018) and in Al-Murib et al. (2019).

\subsection{TDS Calibration}

Model predictions of TDS constituents were compared to the measurements in the Tigris River when field data were available (Fig. 11). In-situ monthly average data of total dissolved solids were provided by the IMWR at MosulDam, Samarra Barrage, Baghdad and Kut Barrage. Some factors such as relatively low flowrates, high TDS concentrations introduced to the mainstem of the Tigris River upstream of Baghdad through the Tharthar-Tigris canal, and ungaged irrigation return flows that were directly discharged into the mainstem of the Tigris River through numerous man made irrigation channels along both river banks caused high TDS in the mainstem of the river at Baghdad (Fig. 11c) and Kut (Fig. 11d) during the first two months of the year (winter time). Considerable irrigation return flows enter the river system, and TDS concentrations in the Tigris River significantly increased from $280 \mathrm{mg} / \mathrm{L}$ at the Turkey-Iraqi border to $1500 \mathrm{mg} / \mathrm{L}$ at Amara city, located $200 \mathrm{~km}$ south of Kut Barrage (World Bank 2006). Therefore, a tributary was introduced into the mainstem of the Tigris River and was placed downstream of Samarra Barrage to account for high TDS concentration in Baghdad during the first two months of the year to adjust for the deficit in TDS concentrations during the winter months. No calibration parameters were adjusted during calibration. However, calibration process was carried out by adjusting the inflow TDS boundary conditions. As TDS concentrations decreased with increasing dilution (Ansari et al 2012), the initial condition of TDS at Tharthar Lake was $1300 \mathrm{mg} / \mathrm{L}$ and dropped down to about $1150 \mathrm{mg} / \mathrm{L}$ at the end of the simulation due to a continuous dilution through Tigris Tharthar canal. However, field data of TDS in Tharthar Lake were not available for model comparison. Table 6 lists error statistics of model predictions for TDS compared with the monthly averaged field data at Samarra Barrage, Baghdad city and Kut Barrage. 

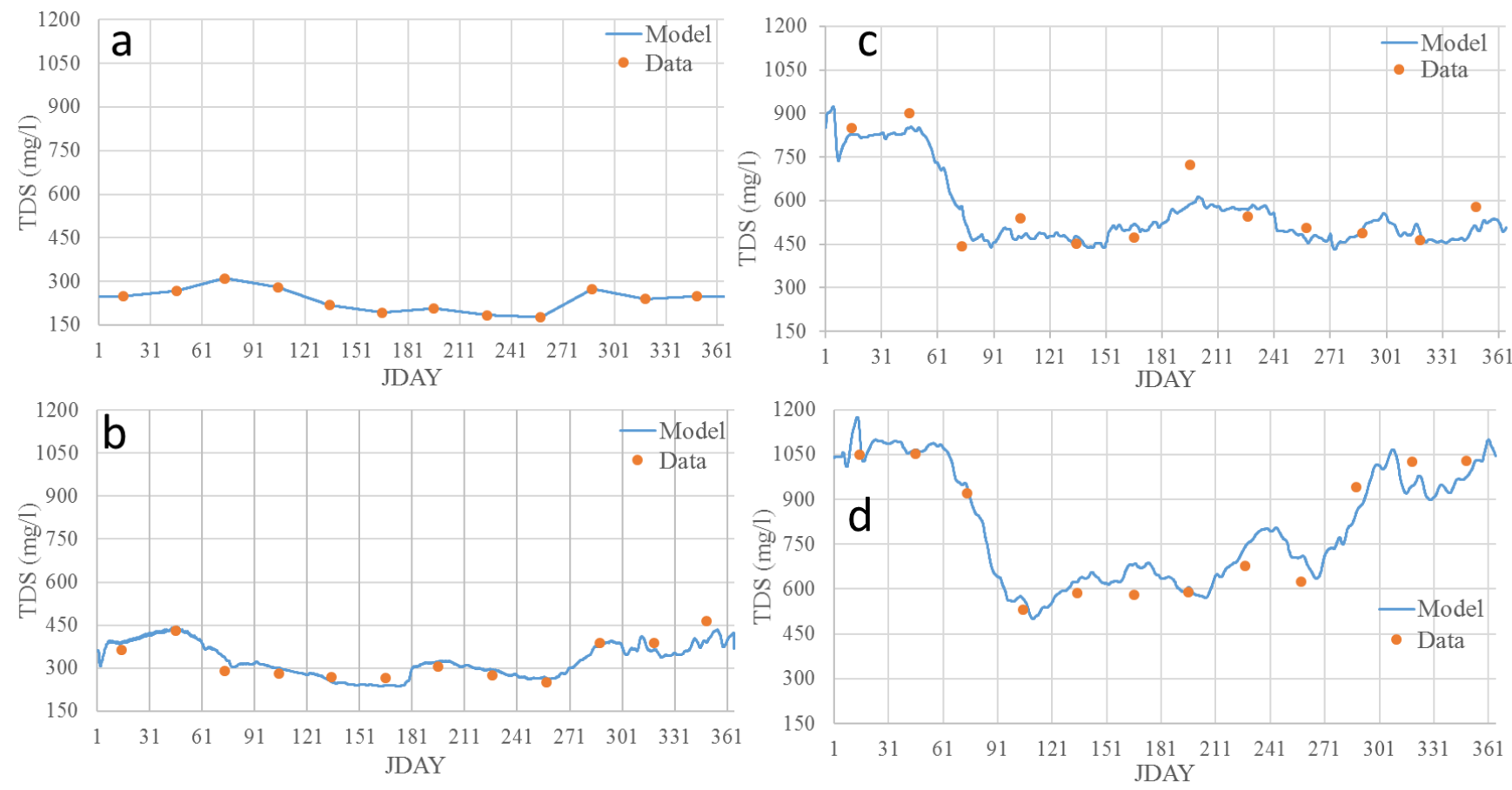

Fig. 11 Model TDS predictions compared to the Tigris River field data at: (a) Mosul; (b) Samarra Barrage; (c) Baghdad; (d) Kut Barrage.

Table 6 Error statistics for model predictions of TDS in the middle of the month compared to field data

\begin{tabular}{cccc}
\hline Error & Samarra Barrage & Baghdad & Kut Barrage \\
\hline ME (mg/L) & 2.6 & -12.9 & 17.7 \\
AME (mg/L) & 27.1 & 53.2 & 53.2 \\
RMSE (mg/L) & 31.7 & 64.8 & 60.4 \\
\# of & 12 & 12 & 12 \\
comparisons, $n$ & & & \\
\hline
\end{tabular}

\section{Model Management Scenarios}

To obtain better insight into the factors which impact total dissolved solids (TDS) in the Tigris River, multiple scenarios were implemented to simulate the effect of changing management of upstream hydrology and the impact of disconnecting Tharthar Lake from the Tigris River system. These scenarios were then compared with the base model showing existing conditions of the simulated year 2009.

Hydrology of the Tigris River system has been significantly impacted by flows entering Iraq at the Turkey-Iraq border. According to Al-Ansari and Knutsson (2011), the mean annual discharge of the Tigris River at Mosul Dam has decreased by $15 \%$ since 1984. To compare with the historical flow before 1984 when Turkey began exerting more control over the flow of the Tigris, flow boundary conditions at MosulDam were increased by $15 \%$ over 2009 levels to study its impact on downstream TDS during this year. Compared with the base model, increasing only upstream 
river flow by $15 \%$ (Fig. 12a) resulted in decrease in the average TDS concentrations of the Tigris River and Tharthar Lake by $5 \%$ and $1 \%$, respectively.

In the future and as a result of constructing several new dams in Turkey, river discharge in the Tigris River is expected to continue to decrease. Therefore, we also studied the effect of potential decrease in upstream flow by an additional 15\%. The upstream flow boundary condition of the Tigris River system at Mosul Dam was decreased by 15\% (Fig. 12b) to study the effect of altering flow on the mainstem of the river and thereby also decreasing the flow to Tharthar Lake. As was expected, concentrations of TDS concentrations increased with decreasing upstream flow at MosulDam due to a decrease in dilution. TDS concentrations were increased by 6.5\% (from $495 \mathrm{mg} / \mathrm{L}$ to $527 \mathrm{mg} / \mathrm{L}$ ) in the mainstem of the Tigris River and by $1.1 \%$ (from $1239 \mathrm{mg} / \mathrm{L}$ to $1253 \mathrm{mg} / \mathrm{L}$ ) in Tharthar Lake.

Although Tharthar Lake is the only storage reservoir that protects the Tigris River from flooding, we also evaluated the impact of disconnecting Tharthar Lake and its canals (Tigris-Tharthar canal, Tharthar arm and Tharthar-Tigris canal) on the TDS concentration in the mainstem of the Tigris River. Therefore, Tharthar Lake and its canals were disconnected from the entire system (Fig. 12c). TDS concentrations in the mainstem of the Tigris River showed a significant decrease by $25 \%$ due to a high volume of water passing Baghdad and downstream cities through Samarra Barrage. 

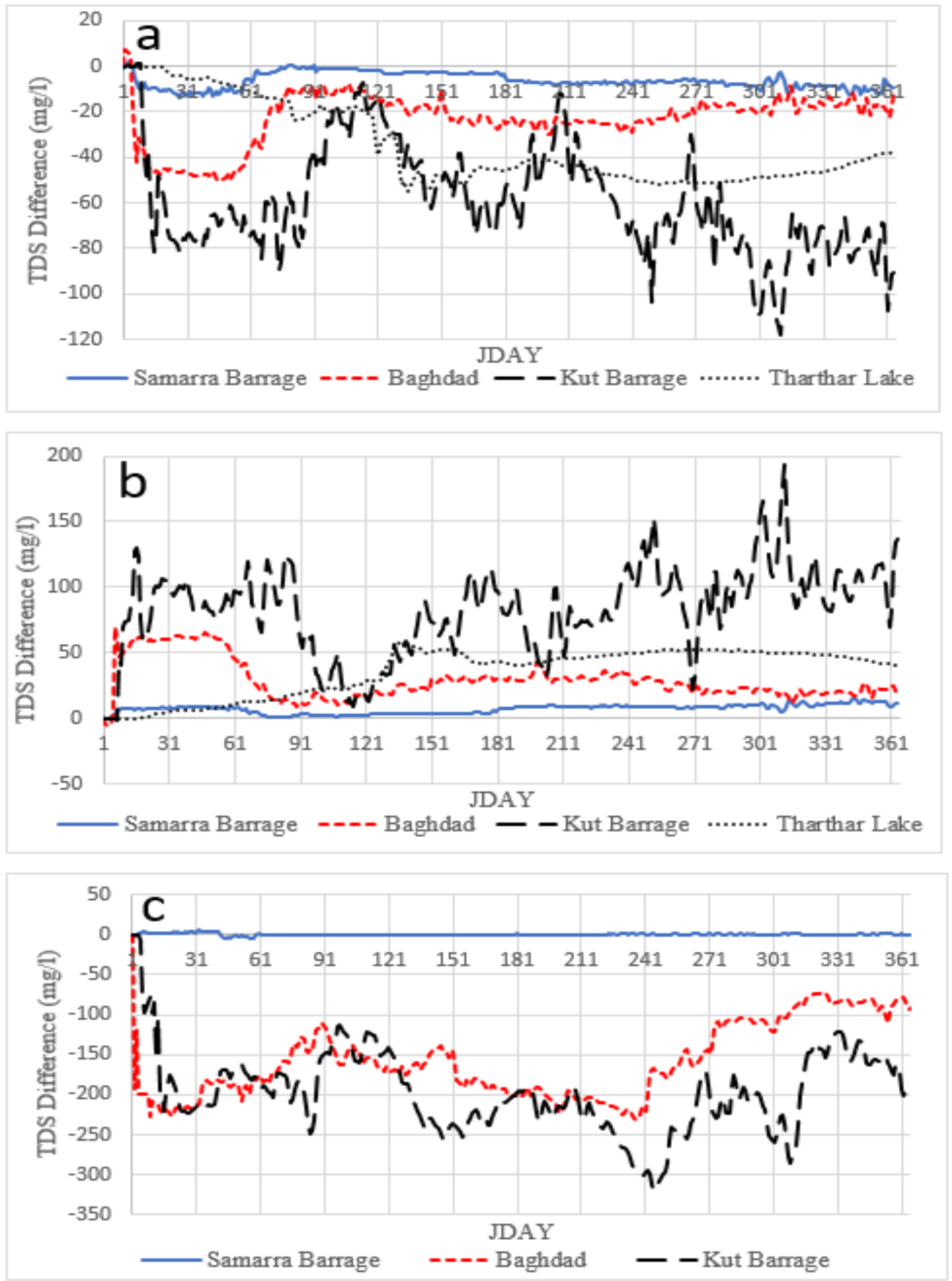

Fig. 12 Total dissolved solids (TDS) difference between model predictions for the base model (existing conditions) and management scenarios: (a) increasing upstream flow by 15\%; (b) decreasing upstream flow by $15 \%$; and (c) disconnecting Tharthar Lake from the Tigris River system. 


\section{Conclusions}

Water flow, stage, temperature and total dis solved solids (TDS) of the Tigris River mainstem from MosulDam (River $\mathrm{km} \mathrm{0)}$ to Kut Barrage (River $\mathrm{km} \mathrm{880)}$ ) and Tharthar Lake with its canals were modeled using the 2-D (x-z) hydrodynamic and water quality model CE-QUAL-W2. The Tigris River systemwas divided into 9 waterbodies and branches with 343 total longitudinal segments with vertical layers of $1 \mathrm{~m}$ height. The model was calibrated using limited field data from January 1st, 2009 to December 31st, 2009. Management scenarios were performed and compared with the base model of the Tigris River to give more insight into how TDS responds to altering upstream hydrology at Mosul dam and to disconnecting Tharthar Lake from the Tigris River system.

Model predictions of flow and water level were calibrated at Baeji, Samarra Barrage and Baghdad. The absolute mean error of flow was recorded as $12.6 \mathrm{~m}^{3} / \mathrm{s}, 3.7 \mathrm{~m}^{3} / \mathrm{s}$ and $3.4 \mathrm{~m}^{3} / \mathrm{s}$ at Baeji with peak flows of $1700 \mathrm{~m}^{3} / \mathrm{s}, \mathrm{Samarra}$ Barrage with peak flows of $600 \mathrm{~m}^{3} / \mathrm{s}$, and Baghdad with peak flows close to $600 \mathrm{~m}^{3} / \mathrm{s}$, respectively. To allow flow calibration, a distributed tributary was added to the Tigris River model to account for ungaged flow such as ground water, runoff, and irrigation return flow. On average, percentage errors of flowrate at Baeji, Samarra Barrage, and Baghdad were $1.93 \%, 0.83 \%$, and $0.81 \%$, respectively. On the other hand, high Manning friction in the Tigris River within Baghdad was observed because of channel irregularities, obstructions, meandering, and inaccuracies in the cross-sectionalgeometry. Model predictions of water level in the Tigris River were less than $0.1 \mathrm{~m}$ in absolute mean error at three river locations. The model friction factors were adjusted to match water level data. Also, water level predictions in Tharthar Lake matched the one data point in October 2009 as a result of en suring that the evaporation rate agreed with field data in a nearby lake.

Model predictions of TDS were compared to field data at Samarra Barrage, Baghdad, and Kut Barrage. The absolute mean error of TDS calibration was recorded as $27 \mathrm{mg} / \mathrm{L}, 53 \mathrm{mg} / \mathrm{L}$, and $53 \mathrm{mg} / \mathrm{L}$ at Samarra Barrage, Baghdad, and Kut Barrage, respectively. TDS concentrations in the Tigris River varied from 300 to over $1000 \mathrm{mg} / \mathrm{L}$. It was concluded that the average TDS concentration in the mainstem of the Tigris River could be maintained below $500 \mathrm{mg} / \mathrm{L}$ if the average annual flow in the Tigris River within Baghdad was maintained above $420 \mathrm{~m}^{3} / \mathrm{s}$. Diverted water from Tharthar Lake to the mainstem of the Tigris River upstream of Baghdad, unregulated effluents from three wastewater treatment plants within Baghdad, and irrigation return flow in Baghdad and downstream caused a significant increase in TDS concentrations in the Tigris River. Although highly saline water was discharged to the mainstem of the Tigris River upstream of Baghdad through the Audiam River, this did not significantly contribute to increasing TDS concentration in the mainstem because the flowrates were very low.

To improve water quantity and quality of the Tigris River, better monitoring field data (flow, temperature, TDS) would provide better boundary condition field data for the model. This study did show that by using a basic model framework with limited data, data gaps could be filled that led to a reasonable calibration to field data. The boundary conditions that would most affect water quality in the river include the outflow from MosulDam and flows from the Upper Zab tributary which is the largest contributor to the Tigris River. Knowing unregulated water withdrawals along the Tigris River as a result of irrigation demand would also improve the predictive ability of the model. The high TDS entering the Tigris River is largely from Tharthar Lake as a result of evaporation, as well as from agricultural return flows which are largely unknown. To keep TDS concentrations in the Tigris River system within acceptable levels, wastewater should efficiently be treated before discharging into the river system. Also, man-made canals used for irrigation could strictly be monitored to regulate and control the impact of irrigation return flow on the mainstem of the Tigris River.

A modeled 15\% increase in upstream flow at Mosul Dam showed a decrease in the average TDS concentrations from $495 \mathrm{mg} / \mathrm{L}$ to $470 \mathrm{mg} / \mathrm{L}$ in the mainstem, while modeled 15\% decrease in upstream flow at Mosul Dam showed an increase in TDS concentrations from $495 \mathrm{mg} / \mathrm{L}$ to $527 \mathrm{mg} / \mathrm{L}$ in the mainstem. Disconnecting Tharthar Lake from the Tigris River system significantly affected the hydrologic regime downstream of Samarra Barrage by passing $36 \%$ 
more water from Samarra Barrage to Baghdad causing a substantialdecrease in TDS concentration by $25 \%$ as a result of low TDS water moving downstream.

\section{Acknowledgements}

The authors would like to thank the Iraqi Ministry of Water Resources and the Iraqi Ministry of Transportation for providing field data used in this research. Thanks are also extended to the anonymous reviewers for the ir time and effort providing valuable comments that significantly enhanced the paper.

Conflict of Interest: The authors declare that they have no conflict of interest.

\section{References}

Al-Ansari N (2013) Management of water resources in Iraq: perspectives and prognoses. Eng 05 (08): $667-684$. https://doi.org/10.4236/eng.2013.58080.

Al-Ansari N, Ali A, Al-Suhail Q, Knutsson S (2015) Flow of river tigris and its effect on the bed sediment within Baghdad, Iraq. Open Eng 5 (1): 465-477. https://doi.org/10.1515/eng-2015-0054.

Al-Ansari N, Knutsson S (2011) Toward prudent management of water resources in Iraq. J Adv Sci Eng Res 1: 5367.

Al-Janabi K, Alazawi F, Mohammed M, Kadhum A, Mohamad A (2011) Chlorophenols in tigris river and drinking water of Baghdad, Iraq. Bull Environ Contam Toxicol 87 (2): 106-112. https://doi.org/10.1007/s00128-01 10315-y.

Al-Jebouri M, Edham M (2012) An as sessment of biological pollution in certain sector of lower al-zab and river tigris waters using bacterial indicators and related factors in Iraq. J Water Resour Prot 04 (01): 32-38. https://doi.org/10.4236/jwarp.2012.41005.

Al-Layla M, Al-Rizzo H (1989) A water quality model for the tigris river downstream of Sadam dam, Iraq. Hydrol Sci J 34 (6): 687-704. https://doi.org/10.1080/02626668909491375.

Al-Murib M (2014) Application of CE-QUAL-W 2 on Tigris River in Iraq. Thesis, Portland State University

Al Murib M (2018) Hydrodynamic and Water Quality Modeling of the Tigris River System in Iraq Using CE-QUALW2. Dis sertation, Portland State University

Al-Murib M, Wells S, Talke S (2019 ) Integrating landsat TM/ETM+ and numerical modeling to estimatewater temperature in the tigris river under future climate and management scenarios. 11, 892. doi:10.3390/w11050892

Al-Rawi S (2005) Contribution of man-made activities to the pollution of the tigris within Mosul area/Iraq. Int J Environ Res Public Health 2 (2): 245-250. https://doi.org/10.3390/ijerph2005020007.

Ali A, Al-Ansari N, Knutsson S (2012) Morphology of tigris River within Baghdad city. Hydrol Earth Syst Sci 16 (10): 3783-3790. https://doi.org/10.5194/hess-16-3783-2012.

Ansari F, Awasthi A, Srivastava B (2012) Physico-chemical characterization of distillery effluent and its dilution effect at different levels. Sch Res Libr Arch Appl Sci Res 4 (4): 1705-1715.

Aziz A, Aws A (2012) Waste water production treatment and use in Iraq. http://www.ais.unwater.org/ais/pluginfile.php/356/mod_page/content/114/Iraq_WasteWaterProduction.pdf. Accessed 18 February 2019 
Baldassarre G, Montanari A (2009) Uncertainty in river discharge observations: a quantitative analysis. Hydrol Earth Syst Sci 13 (6): 913-921. https://doi.org/10.5194/hess-13-913-2009.

Berger C, Wells S (2008) Modeling the effects of macrophytes on hydrodynamics. J Environ Eng 134 (9): 778-788.

Berger C, Wells S, Al-Murib M (2018) Tualatin River Model Development and Calibration 2013-2015. Technical Report prepared for Clean Water Services, Hillsboro, OR.

Charbeneau R, Holley E (2001) Backwater effects of bridge piers in subcritical flow. http://ctr.utexas.edu/wpcontent/uploads/pubs/1805_S.pdf. Accessed 18 February 2019

Chow V (1959) Open Channel Hydraulics. McGraw-Hill Book Company, Inc. USA

Cohn T, Kiang J, Mason R (2013) Estimating discharge measurement uncertainty using the interpolated variance estimator. J Hydraul Eng 139 (5): 502-510. https://doi.org/10.1061/(ASCE)HY.1943-7900.0000695.

Cole T, Wells S (2017) CE-QUAL-W2: A two-dimensional, laterally averaged, hydrodynamic and water quality model, Version 4.1. Technical Report, Department of Civil and Environmental Engineering, Portland State University, Portland, OR, USA. http://www.cee.pdx.edu/w2/ Accessed 15 July 2018

CSO (2010) Central Statistical Organization in Iraq-Environmental Statistics Report in Iraq for the year 2009. In Arabic. http://www.cosit.gov.iq/ar/env-stat/envi-stat Accessed 21 April 2017

FAO (2008) Irrigation in the Middle East Region in Figures.

http://www.fao.org/tempref/agl/AGLW/docs/wr34_eng.pdf Accessed 20 August 2018

FAO (2012) Iraq-Agriculture sectore note.

http://www.fao.org/3/i2877e/i2877e.pdf Accessed 20 August 2018

Issa I, Al-Ansari N (2014) Expected future of water resources within tigris-euphrates rivers basin, Iraq. Water Resour Prot, 6: 421-432. https://doi.org/10.4236/jwarp.2014.65042.

Kadhem A (2013) Assessment of Water Quality in Tigris River-Iraq by Using GIS Mapping. Nat Resour 04 (06): 441-448. https://doi.org/10.4236/nr.2013.46054.

Khattab M, Merkel B (2014) Application of Landsat 5 and Landsat 7 Images Data for Water Quality Mapping in MosulDam Lake, Northern Iraq. Arab J Geosci 7 (9): 3557-3573. https://doi.org/10.1007/s 12517-013-1026-y.

Kim Y, Kim B (2006) Application of a 2-dimensional water quality model (CE-QUAL-W 2) to the turbidity interflow in a deep reservoir (lake soyang, Korea). Lake Reserv Manag 22 (3): 213-222. https://doi.org/10.1080/07438140609353898.

Ma J, Liu D, Wells S, Tang H, Ji D, Yang Z (2015) Modeling density currents in a typical tributary of the three gorges reservoir, China. Ecol Modell 296: 113-125. https://doi.org/10.1016/j.ecolmodel.2014.10.030.

Mutlak S, Salih B, Tawfiq S (1980) Quality of tigris river passing through Baghdad for irrigation. Water Air Soil Pollut 13: 9-16.

Odemis B, Sangun M, Evrendilek F (2010) Quantifying long-term changes in water quality and quantity of euphrates and tigris rivers, Turkey. Environ Monit Assess 170: 475-490. https://doi.org/10.1007/s 10661-009-1248-3.

Othman K, Deguan W (2004) Characteristics of tigris river bed at Mosul city, Iraq. J Lake Sci 16: 61-70.

Park Y, Cho K, Kang J-H, Lee S, Kim J (2014) Developing a flow control strategy to reduce nutrient load in a reclaimed multi-reservoir systemusing a 2D hydrodynamic and water quality model. Sci Total Environ 466467: 871-80. https://doi.org/10.1016/j.scitotenv.2013.07.041.

Rabee A, Abdul-Kareem B, Al-Dhamin A (2011) Seasonal variations of some ecological parameters in tigris river water at Baghdad region, Iraq. J Water Resour Prot 03 (04): 262-267. https://doi.org/10.4236/jwarp.2011.34033.

Rahi K, Halihan T (2010) Changes in the salinity of the euphrates river system in Iraq. Reg Environ Change 10 (1): 27-35. https://doi.org/10.1007/s 10113-009-0083-y.

Sissakian V (2011) Genesis and age estimation of the tharthar depression, central west Iraq. Iraqi Bull Geol Min 7 (3): $47-62$. 
Unver I (1997) South-eastern anatolia integrated development project (GAP), Turkey: an overview of issues of sustainability. International J Water Resour Dev 13 (2): 187-208. https://doi.org/10.1080/07900629749827.

Van Glubt S, Wells S, Berger C (2017) Hydrodynamic and water quality modeling of the chehalis river in Washington. Proceedings ASCE EWRI Congress, Sacramento, May 21-25. DOI: http://dx.doi.org/10.1061/9780784480601.019

Varol M, Gökot B, Bekleyen A (2013) Dissolved heavy metals in the tigris river (Turkey): spatial and temporal variations. Environ Sci Pollut Res 20 (9): 6096-6108. https://doi.org/10.1007/s11356-013-1627-8.

Wells S, Berger C (2016) Modeling the response of dissolved oxygen to phosphorus loading in lake spokane. Lake and Reserv Manag 32 (3): 270-279. https://doi.org/10.1080/10402381.2016.1211910.

WHO (2008) Guidelines on health aspects of water desalination. ETS/80.4. Geneva: World Health Organization.

World Bank (2006) Iraq: Country Water Resource Assistance Strategy: Addressing Major Threats to People's Livelihoods. http://siteresources.worldbank.org/INTWAT/Resources/Iraq.pdf Accessed 20 February 2019

\section{Appendix A CE-QUAL-W2 Governing Equations}

The water quality state variables include (Cole and Wells 2017):

1. any number of generic constituents defined by a 0 and/or a 1st order decay rate and/or a settling velocity and/or an Arrhenius temperature rate multiplier that can be used to define any number of the following:
a. conservative tracer(s)
b. water age or hydraulic residence time
c. $\mathrm{N}_{2}$ gas and \% Total Dissolved Gas
d. coliform bacteria(s)
e. contaminant(s)

2. any number of inorganic suspended solids groups

3. any number of phytoplankton groups

4. any number of periphyton/epiphyton groups

5. any number of CBOD groups

6. any number of submerged macrophyte groups

7. ammonium

8. nitrate+nitrite

9. bioavailable phosphorus (commonly represented by orthophosphate or soluble reactive phosphorus)

10. silica (dissolved and particulate)

11. labile dissolved organic matter

12. refractory dissolved organic matter

13. labile particulate organic matter

14. refractory particulate organic matter

15. total inorganic carbon

16. alkalinity

17. iron and manganese

18. dis solved oxygen

19. organic sediments

20. gas entrainment

21. any number of macrophyte groups

22. any number of zooplankton groups

23. labile dissolved organic matter-P

24. refractory dissolved organic matter-P

25. labile particulate organic matter-P

26. refractory particulate organic matter-P

27. labile dissolved organic matter-N

28. refractory dissolved organic matter-N

29. labile particulate organic matter-N 
30. refractory particulate organic matter-N

31. Sediment and water column $\mathrm{CH}_{4}$

32. Sediment and water column $\mathrm{H}_{2} \mathrm{~S}$

33. Sediment and water column $\mathrm{SO}_{4}$

34. Sediment and water column Sulfide

35. Sediment and water column $\mathrm{FeOOH}(\mathrm{s})$

36. Sediment and water column $\mathrm{Fe}^{+2}$

37. Sediment and water column $\mathrm{MnO}_{2}$ (s)

38. Sediment and water column $\mathrm{Mn}^{+2}$

39. Sediment organic $\mathrm{P}$, sediment $\mathrm{PO}_{4}$

40. Sediment organic $\mathrm{N}$, sediment $\mathrm{NO}_{3}$, sediment $\mathrm{NH}_{4}$

41. Sediment Temperature

42. Sediment $\mathrm{pH}$

43. Sediment alkalinity

44. Sediment Total inorganic C

45. Sediment organic C

46. Turbidity correlation to Suspended solids

\section{Governing Equations}

X-Momentum

$$
\frac{\partial U B}{\partial t}+\frac{\partial U U B}{\partial x}+\frac{\partial W U B}{\partial z}=-\frac{1}{\rho} \frac{\partial B P}{\partial x}+\frac{\partial\left(B A_{x} \frac{\partial U}{\partial x}\right)}{\partial x}+\frac{\partial B \tau_{x}}{\partial z}
$$

Where

$$
\begin{aligned}
& \mathrm{U}=\text { longitudinal, laterally averaged velocity, } \mathrm{m} / \mathrm{s} \\
& \mathrm{B}=\text { water body width, } \mathrm{m} \\
& \mathrm{t}=\text { time, } \mathrm{s} \\
& \mathrm{x}=\text { longitudinal Cartesian coordinate } \\
& \mathrm{Z}=\text { vertical Cartesian coordinate } \\
& \mathrm{W}=\text { vertical, laterally averaged velocity, } \mathrm{m} / \mathrm{s} \\
& \rho=\text { density, } \mathrm{kg} / \mathrm{m}^{3} \\
& \mathrm{P}=\text { pressure, } \mathrm{N} / \mathrm{m}^{2} \\
& \mathrm{~A}_{\mathrm{x}}=\text { longitudinal momentum } \mathrm{dispersion}^{2} \text { coefficient }, \mathrm{m}^{2} / \mathrm{s}^{2} \\
& \tau_{\mathrm{x}}=\text { shear stress per unit mas } \mathrm{s}, \mathrm{m}^{2} / \mathrm{s}^{2}
\end{aligned}
$$

\section{Z-Momentum}

$$
0=g-\frac{1}{\rho} \frac{\partial P}{\partial z}
$$

Where

$$
\mathrm{g}=\text { acceleration due to gravity, } \mathrm{m} / \mathrm{s} 2
$$

Continuity

$$
\frac{\partial U B}{\partial x}+\frac{\partial W B}{\partial z}=q B
$$


Where

$\mathrm{q}=$ lateral boundary inflow or outflow, $\mathrm{m} 3 / \mathrm{s}$

Free-Surface

$$
\frac{\partial B_{\eta} \eta}{\partial t}=\frac{\partial}{\partial x} \int_{\eta}^{h} U B d z-\int_{\eta}^{h} q B d z
$$

Where

$$
\begin{aligned}
& \mathrm{B}_{\eta}=\text { spatially and temporally varying surface width, } m \\
& \eta=\text { free water surface location, } m \\
& \mathrm{~h}=\text { total depth, } \mathrm{m}
\end{aligned}
$$

Constituent Transport

$$
\frac{\partial B \varphi}{\partial t}+\frac{\partial U B \varphi}{\partial x}+\frac{\partial W B \varphi}{\partial z}-\frac{\partial\left(B D_{x} \frac{\partial \varphi}{\partial x}\right)}{\partial x}-\frac{\partial\left(B D_{z} \frac{\partial \varphi}{\partial z}\right)}{\partial z}=q_{\varphi} B+S_{k} B
$$

Where

$\varphi=$ laterally averaged constituent concentration, $\mathrm{mg} / \mathrm{L}$

$\mathrm{D}_{\mathrm{x}}=$ longitudinal temperature and constituent dis persion coefficient, $\mathrm{m}^{2} / \mathrm{s}$

$\mathrm{D}_{\mathrm{z}}=$ vertical temperature and constituent dispersion coefficient, $\mathrm{m}^{2} / \mathrm{s}$

$\mathrm{q}_{\varphi}=$ lateral inflow or outflow mass flow rate of constituent per unit volume, $\mathrm{mg} / \mathrm{L} / \mathrm{s}$

$\mathrm{S}_{\mathrm{k}}=$ kinetics source/sink term for constituent

Equation of State

$$
\rho=f\left(T, \varphi_{T D S}, \varphi_{S S}\right)
$$

Where

$\mathrm{T}=$ temperature, ${ }^{\circ} \mathrm{C}$

$\varphi_{\mathrm{TDS}}=$ total dis solved solids concentration, $\mathrm{mg} / \mathrm{L}$

$\varphi_{\mathrm{SS}}=$ suspended solids concentration, $\mathrm{mg} / \mathrm{L}$ 